\title{
The Translation of Dune An Encounter of Languages
}


Alice Ray - Contacts and Contrasts (Konin) - 29-31 mai 2017 


\section{Science Fiction and Fiction Words}

"Science fiction, with its freedom to create unearthly worlds as well as to explore and distort time and space, may give new vitality to the dream of human experience."

(Clareson, 1971, p. 25)

"A good science-fiction story is a story with a human problem, and a human solution, which would not have happened at all without its science content"

(Sturgeon quoted by Blish, 1971, p. 167)

"The aliens - utopians, monsters or simply differing strangers - are a mirror to man just as the differing country is a mirror for his world. But the mirror is not only a reflecting one, it is also a transforming one, virgin womb and alchemical dynamo: the mirror is a crucible."

(Suvin, 1972, p. 374) 


\section{Science Fiction and Fiction Words}

Cognitive estrangement (after dramatist's concept Bertolt Brecht) : "the effect brought on by the reader's realization that the setting of a text (film, etc.) differs from that of the reader's reality, especially where the difference is based on scientific extrapolation, as opposed to supernatural of fantastic phenomena."

(Prucher, 2007, p. 23)

"Cognitive estrangement is the sense that something in the fictive world is dissonant with the reader's experience world."

(Mendlesohn quoted in Prucher, 2007, p. 23)

Fiction (or fictive) words :

"Words created by SF writers to convey a feeling of estrangement are not at all neologisms but 'fictive words' (...) [:] words that supposedly anticipate forms of language from the future or from 'parallel' universes"

(Angenot, 1979) 


\section{Science Fiction and Fiction Words}

Vidscreen : "communications device capable of transmitting and receiving the voice and image of the users [see videophone definition]"

(Prucher, 2007, p. 261)

"vidscreen" context :

"The technician in charge of the night shift at the map room coughed nervously as the massive, sloppy head of Glen Runciter swam up to fill the vidscreen."

(Dick quoted in Prucher, 2007, p. 262)

\section{Fiction words :}

1. Fiction words $>$ one term which doesn't exist in the readers' dictionary

2. Fiction expressions $>$ two or more terms, invented or not, which create a new concept or a new object together.

a. ex. "geriatric spice" (Herbert, 1990, p. 5)

3. Fiction senses $>$ not invented terms which convey a new and different meaning(s) that dictionaries' ones.

1. Ex. "Voice" (Herbert, 1990, p. 10) : ability to control other people's mind with the sound of the voice. 


\section{Dune loanwords}

"Dune is to science fiction what The Lord of the Rings is to fantasy: the ultimate created world"

(Pierce, 1987:123)

"Dune (...) is a historical mural painting of humanity (...) whose language, especially foreign languages (...) is a crucial and very original feature of the work"

FRANK HERBERT THE GREATEST SCIENCE FICTION NOVEL OF ALL TIME DI Ine
(Plante Jourdain, 2001-2002:81)

"Here is the novel that will be forever considered a triumph of the imagination. Set on the desert planet Arrakis, Dune is the story of the boy Paul Atreides, who would become the mysterious man known as Muad'Dib. He would avenge the traitorous plot against his noble family - and would bring to fruition humankind's most ancient and unattainable dream."

Back cover of Dune, 1990, Ace Books 


\section{Dune loanwords}

\begin{tabular}{lll}
\hline \multicolumn{1}{c}{ Loanwords } & Definition in Dune & Original language \\
\hline Bashar & Sardaukar officer & Arabic \\
kanly & Vendetta & Turkish \\
Verite & Drug & French \\
Kindjal & Short sword & Persian \\
Kwisatz Haderach & Name of an & Hebrew \\
& extraordinary man & \\
Missionaria & Bene Gesserit ritual to & Latin \\
Protectiva & exploit primitive & \\
& worlds & \\
schlag & Animal & German \\
sadus & Holy judge & Sanskrit \\
Nezhoni scarf & Scarf worn by new & Navajo \\
& mother & \\
\hline
\end{tabular}




\section{Arabic loanwords in the original text of Dune}

\section{Loanwords :}

"As for loanword, defining it is complicated and several categorisations are possible according to different criterion (...) :

a) loanwords conveying a signifié which, in a first time, is not attested in the target language and which would enhance it with a notion or a signifié one could not designate otherwise (...)

b) Loanwords conveying a signifié which in the target language could be said with a pre-existing term. In this case, it is rather a stylistic choice determined by complicated factors among which the impact of cultural and linguistic trends seem to be important.

c) Loanwords which on the semantic level are slightly different from one language to another, for example 'jogging' which corresponds in French to 'race' and to 'tracksuit' while in Italian, the same term only means 'race'."

(Caputo, Enrico and Masucci, 1987, p. 268-269) 


\section{Arabic loanwords in the original text of Dune}

\begin{tabular}{|c|c|c|c|}
\hline Loanwords & Dune definition & Arabic words & Arabic definition \\
\hline Muad'Dib & $\begin{array}{l}\text { Fremen name of Paul Atreides. } \\
\text { "the adapted kangaroo mouse } \\
\text { of Arrakis (...), admired by the } \\
\text { Fremen for its ability to survive } \\
\text { in the open desert" }\end{array}$ & Mu'addib & $\begin{array}{l}\text { One who teaches especially the } \\
\text { first rule of Muslim religion }\end{array}$ \\
\hline shari-a & $\begin{array}{l}\text { "the part of the panoplia } \\
\text { propheticus which sets forth } \\
\text { the superstitious ritual" }\end{array}$ & Shari'a & Religious laws \\
\hline al-Lat & “mankind's original sun" & al-Lat & $\begin{array}{l}\text { Pre-Islamic goddess of } \\
\text { fecundity personifying the sun }\end{array}$ \\
\hline jihad & A religious and fanatic crusade & jihad & $\begin{array}{l}\text { Muslim religious war } \\
\text { Literally "effort" }\end{array}$ \\
\hline hajra & "journey of seeking" & hijrah & Departure, exodus, migration \\
\hline alam al-mithal & $\begin{array}{l}\text { "the mystical world of } \\
\text { similitudes where all physical } \\
\text { limitations are removed" }\end{array}$ & alam al-mithal & The world of analogies \\
\hline ichwan bedwine & $\begin{array}{l}\text { "the brotherhood of all } \\
\text { Fremen" }\end{array}$ & Ikhwan & Fraternity \\
\hline fedaykin & "Fremen death commandos" & Fedayeen & $\begin{array}{l}\text { military groups willing to } \\
\text { sacrifice themselves }\end{array}$ \\
\hline taqwa & $\begin{array}{l}\text { "Something of great value. } \\
\text { That which a deity demands of } \\
\text { a mortal and the fear provoked } \\
\text { by the demand" }\end{array}$ & taqwa & $\begin{array}{l}\text { Piety } \\
\text { God-fearing }\end{array}$ \\
\hline
\end{tabular}




\section{Arabic loanwords in the original text of Dune}

"'I see a...Fremen with the book of example,' she intoned. 'He reads to al-Lat, the sun whom he defied and subjugated."

(Herbert, 1990, p. 475)

"Jessica thought about the prophecy - the Shari-a and all the panoplia propheticus, a Bene Gesserit of the Missionaria Protectiva dropped here long centuries ago - long dead, no doubt, but her purpose accomplished (...)"

(ibid, p. 88)

"'The Reverend Mother tells me she cannot survive another hajra,' Stilgar said." (ibid, p. 569)

"'I order the full ceremony. Jamis was our companion and brother of the Ichwan Bedwine. There shall be no turning away without the respect due one who proved our fortune by his tahaddi challenge."

(ibid, p. 499)

"I will say it once more: I've given the tribe's word-bond. My people know your worth to us now. What could the Harkonnens give us? Our freedom? Hah! No, you are the taqwa, that which buys us more than all the spice in the Harkonnen coffers."

(ibid, p. 457) 


\section{Arabic loanwords in the French translation of Dune}

" Je vois un... Fremen avec le livre des exemples. II le lit à al-Lat, le soleil qu'il défie et domine. "

(Herbert, 1985, p. 303)

« La prophétie...Le Shari-a et toute la panoplia propheticus. Un Bene Gesserit de la Missionaria Protectiva envoyée sur ce monde combien de siècles auparavant, morte depuis longtemps, sans aucun doute, mais ayant atteint son but (...) ॥

(ibid, p. 62)

" La Révérence Mère me dit qu'elle ne pourrait survivre à un autre hajra, reprit Stilgar. »

(ibid, p. 359)

"Quant à Jamis, dit-il, la cérémonie sera pleinement célébrée. Il était notre compagnon et frère de l'Ichwan Bedwine. Nous ne nous détournerons pas sans le respect dû à celui qui a mis notre chance à l'épreuve par son tahaddi. "

(ibid, p. 317)

" Je le dis à nouveau: Je vous ai donné la parole de la tribu. Mes gens connaissent maintenant votre valeur. Que pourraient donc nous offrir les Harkonnens? Notre liberté ? Ah... Non, vous êtes le taqwa qui peut nous apporter plus que toute l'épice des coffres des Harkonnens. " 


\section{Arabic loanwords in the French translation of Dune}

\begin{tabular}{|c|c|c|}
\hline English & French & Dune definition \\
\hline alam al-mithal & alam al-Mithal & $\begin{array}{l}\text { "the mystical world of } \\
\text { similitudes where all } \\
\text { physical limitations are } \\
\text { removed" }\end{array}$ \\
\hline dar al-hikman & al-hikman & $\begin{array}{l}\text { "school of religious } \\
\text { translation of } \\
\text { interpretation" }\end{array}$ \\
\hline El-Sayal & El sayal & $\begin{array}{l}\text { "the 'rain of sand'. A fall of } \\
\text { dust which has been } \\
\text { carried to medium altitude } \\
\text { (...) by a coriolis storm" }\end{array}$ \\
\hline mish-mish & mish mish & "apricots" \\
\hline baklawa & baklava & $\begin{array}{l}\text { "a heavy pastry made with } \\
\text { date syrup" }\end{array}$ \\
\hline
\end{tabular}




\section{Arabic loanwords in the French translation of Dune}

Differences can be explained by:

1. Subjectivity and creativity of the translator

2. Grammar or typographic rules of French language.

1. "baklaWa" > "baklaVa"

"a dessert originating in the Middle East made of filo pastry filled with chopped nuts and soaked in honey (Turkish origin)" In the Oxford Dictionary :

"baklava"

In the Larousse Dictionary :

"baklava"

Dictionary of Arabic Cuisine : "baklawa"
2. "dar al-hikman" > "al-hikman"

$>$ Translator's choice.

3. "alam al-mithal" > "alam al-Mithal" $>$ Conceptual and Religious term

4. "el-Sayal" > "el sayal"

> "'El sayal, dit-il, la pluie de sable qui apporte le matin."' (Herbert, 1985, p. 395)

"'El-Sayal, the rain of sand that brings the morning,' he said" (Herbert, 1990, p. 628) 


\section{Arabic loanwords in the French translation of Dune}

« Et s'il est réellement le Kwisatz Haderach...Eh bien... » (Herbert, 1985, p. 9)

«Ce fut mon tahaddi-al-burhan, mon dernier test. » (ibid, p. 198)

« Voici l'ayat et le burhan de la Vie. » (ibid, p. 202)

« Oui, il pouvait encore distinguer la bannière verte et noire des Atréides flottant...quelque part au-devant de la route...les mots sanglants du jihad et les légions fanatiques » (ibid, p. 317)

« La voyante qui vous a apporté la légende, dit-elle, l'a fait par le karama et l'ijaz, le miracle et l'immuabilité de la prophétie. Je sais cela. " (ibid, p. 293)

« La Révérende Mère me dit qu'elle ne pourrait survivre à un autre hajra, reprit Stilgar. " (ibid, p. 359)

" Tout à coup, un Fedaykin aperçut Paul et lança le cri de bataille qui se répercuta dans la grotte (...) » (ibid, p. 425)

« Je suis un Naib, dit Stilgar, que l'on ne prend jamais vivant. " (ibid, p. 396) 


\section{Arabic loanwords in the French translation of Dune}

"Nous te donnerons un nom, petit homme, dit Stilgar, quand viendra le moment de la mihna, au cours de l'épreuve de l'aql. » (Herbert, 1985, p. 296)

> "mihna" = "the season for testing Fremen youths who wish admittance to manhood"

« La Sayyadina, Notre Révérende Mère, est vieille. » (ibid, p. 302)

> "Sayyadina" = "feminine acolyte in the Fremen religious hierarchy" 


\section{Other loanwords in the French translation of Dune}

\begin{tabular}{llll}
\hline Loanwords & \multicolumn{1}{c}{ French } & \multicolumn{1}{c}{ Language } & \multicolumn{1}{c}{ Dune Definition } \\
\hline cherem & haine commune & Hebrew & $\begin{array}{l}\text { "a brotherhood of hate } \\
\text { (usually for revenge)" }\end{array}$ \\
kanly & rétribution & Turkish & $\begin{array}{l}\text { "formal feud or vendetta } \\
\text { under the rules of the Great } \\
\text { Convention carried on } \\
\text { according to the strictest } \\
\text { limitations" }\end{array}$ \\
\hline
\end{tabular}


In science fiction, the contact of languages create another world, another culture based on cultures we know.

The Fremen seem real because they speak a language which appeals both our knowledge and our imagination.

Dune translation in French keeps this feeling of both strangeness and known, adding a new cultural aspect in the novel through the language of translation.

"Whether a thought is spoken or not it is a real thing and it has power," Tuek said. "You might find the line between life and death among the Fremen to be too sharp and quick." 
Angenot, Marc. "The Absent Paradigm: An Introduction to the Semiotics of Science Fiction". Science Fiction Studies 6.17 (1979), URL : http://www.depauw.edu/sfs/backissues/17/angenot17.htm

Bleiler, Richard, ed. Science Fiction Writers: Critical Studies of the Major Authors from the Early Nineteenth Century to the Present Day. New York: Charles Scribner's Sons, 1982.

Blish, James. "On Science Fiction Criticism", in SF: The Other Side of Realism. Bowling Green: Bowling Green University Popular Press, 1971, p. 166-170.

Caputo, Ambra, Emanuela Enrico, et Fabienne Masucci. "Néologismes et contact des langues". Meta: Journal des traducteurs 32.3 (1987), p. 267-272.

Clareson, Thomas D. "The Other Side of Realism", in SF: The Other Side of Realism. Bowling Green: Bowling Green University Popular Press, 1971, p. 1-28.

Dick, Philip K. Ubik. London: Gollancz, 2004.

"Dune books ». WorldCat. URL: http://www.worldcat:org/searchzec or ldcat org all\&q=dune

Herbert, Frank. Dune. Trad. par Michel Demuth. Paris, France: Éd. France loisirs, 1985 [1970].

---. Dune. New York: Ace Books, 1990 [1965].

---. "Terminology of the Imperium", in Dune. New York: Ace Books, 1990 [1965], p. 833-863.

Kennedy, Kara. "Epic World-Building : Names and Cultures in Dune". Names 64.2 (2016), p. 99-108.

Pierce, John J. Foundations of Science Fiction: A Study in Imagination and Evolution. Greenwood Press, 1987.

Plante Jourdain, Claudia. "L'arabe dans la réflexion religieuse de Dune". Mythes, croyances et religions (2001):, p. 81-95.

---. "Le vocabulaire étranger dans la réflexion politique de Dune". Cercles 14 (2005), p. 73-89.

Prucher, Jeff, éd. Brave new words: the Oxford dictionary of science fiction. Oxford, Royaume-Uni: Oxford University Press, 2007.

Stevenson, Angus. Oxford Dictionary of English. Third Edition. Oxford, Royaume-Uni: Oxford University Press, 2010.

Suvin, Darko. "On the Poetics of the Science Fiction Genre". College English 34.3 (1972), p. 372-382. 